\title{
A CRISE DO LIBERALISMO E AS ORIGENS DO “AUTORITARISMO MODERNO» E DO ESTADO NOVO EM PORTUGAL
}

\author{
FERNANDO ROSAS
}

\section{INTRODUÇÃO}

É ponto pacificamente aceite pela historiografia portuguesa do período contemporâneo que a crise do sistema monárquico constitucional finalmente implantado em 1834, após as convulsões posteriores ao pronunciamento liberal de 1820, se abre no início da última década do século XIX.

A crise política, económica e financeira de 1890/91 -marcada pela bancarrota financeira do Estado português simultânea com a tempestade política originada pelo Ultimatum britânico de 11 de Janeiro de 1890 (1) -assinala, na realidade, o início do fim do regime monárqueco derrubado pela revolução republicana de 5 de Outubro de 1910. Mas, como trabalhos recentes acentuaram (2), parece dever significar, mais do que o simples princípio do processo de superação de certa forma de Estado, o começo da longa crise do sistema liberal português que virá desembocar na Ditadura Militar de 1926 e depois no Estado Novo.

Analisar sumariamente alguns dos factores da crise do sistema liberal monárquico português no fim do século passado e as grandes linhas da dinâmica contraditória das alternativas que historicamente lhe buscam suceder, é o objectivo da presente comunicação. No seu contexto se procurarão resumidamente surpreender a emergência e as especificidades do fenómeno do «autoritarismo moderno» e do seu percurso até às origens do Estado Novo.

\section{A CRISE DO SISTEMA LIBERAL MONÁRQUICO}

A vaga de indignação nacionalista anti-britânica que sacode o país, especialmente os seus centros urbanos, após a aceitação pelo rei D. Carlos e pelas instituições políticas supremas da Monarquia do diktat de Londres de

(1) Ultimatum britânico. Em 11 de Janeiro de 1890 o Governo britânico intimou o governo português a abandonar no prazo de poucas horas, sob pena de retaliações políticas e militares, parte dos territórios que explorava entre as colónias africanas de Angola e Moçambique, com vista a possibilitar a expansão britânica para o norte a partir da África do Sul. O ultimatum foi aceite no própio dia pela corôa portuguesa, originando grandes manifestações patrióticas de protesto contra a Grã-Bretanha e a monarquia.

(2) Cf. Manuel Villaverde Cabral, Portugal na Alvorada do século XX, ed. Regra do Jogo, Lisboa, 1979. 
Janeiro de 1890, não se limita a originar uma complexa crise goverantiva: vem evidenciar o impasse do sistema político-institucional da monarquia liberal.

Na violência dos ataques então desencadeados contra o rei, a dinastia de Bragança, a corôa e os seus «áulicos» na governação, em cujo contexto a ofensiva republicanista associa a Monarquia à própria origem da udecadência nacional» que a pátria atravessaria, desenha-se, para além do discurso ideológico e da retórica nacionalista da pequena burguesia republicana, a grave crise de legitimação a que fora conduzido o liberalismo monárquico.

Desde sempre respousando o seu sistema representativo, especialmente na província, nas redes de caciques e influentes locais - habituais sfazedores de eleições» através das «chapeladas» (3) e dos caceteiros por conta dos governos que se alternavam no controlo do aparelho de Estado- o constitucionalismo monárquico associara ao caciquismo, a partir de 1851, com a «paz regeneradora» (4), o rotativismo. Ou seja, o monopólio de dois partidos e das respectivas clientelas no controlo, em regime de alternância, do Governo e dos lugares do Estado. Partidos que com o tempo, e apesar das mudanças ocorridas quanto a um dos parceiros, se tornam política, ideológica e até socialmente indistintos, como típicas associações essencialmente clientelares e distribuidoras de sinecuras nos respectivos turnos de governação; partidos cuja rotatividade consagra, não obstante, o exclusivo acesso à area do poder de uma oligarquia de grandes interesses ligados à terra, aos meios financeiros ou do comércio colonial e internacional.

A não genuidade da representação parlamentar pelo sistema do cacicato e o bloqueio do pluralismo político na governação e na vida política pela olirgarquia rotativa eram agravados por uma legislação eleitoral censitária e restritiva que eliminava da capacidade eleitoral activa a esmagadora maioria dos cidadãos: em 1890, só $5 \%$ da população portuguesa tinha direito a voto. O estrangulamento deste sistema institucional agudizou-se com o desenvolvimento industrial e a urbanização do último quartel do século. Nos principais centros urbanos (a população de Lisboa e Porto aumenta, entre 1890 e 1911, respectivamente $44 \%$ e $40 \%$ ) o advento de novas industrias, o crescimento da burocracia estatal, a expansão dos serviços comerciais e das profissões liberais origina o desenvolvimento polarizado de uma plebe urbana (o proletariado industrail recém-chegado dos campos, o artesanato industrial, as camadas inferiores dos empregados dos serviços públicos, do comércio, etc.) quase completamente destituída do direito de participação no sistema políti-

(3) Designação, na gíria política da época e que permaneceu, das fraudes eleitorais.

(4) «Paz regeneradora». Longo período de acalmia política e social que se sucede ao golpe militar de 1851 do qual resultará o predomínio do Partido Regenerador na vida política e o período designado por Regeneração. 
co. Sobre ela, e tendendo cescentemente a hegemonizar o seu descontentamento político e social, as camadas intermédias da população urbana; a pequena burguesia dos serviços, das profissões liberais, dos pequenos e médios negócios - gente normalmente com rendimentos e cultura que thes permitem votar, mas marginalizados pela oligarquia da àrea do poder e do acesso aos grandes empreendimentos (e rendimentos) económicos e financeiros. É esta a base social típica do republicanismo português que, na viragem do século, conquistará às organizações operárias socialistas e anarcosindicalistas a liderança, como decisiva força de manobra no ataque à monarquia, da plebe urbana.

É ela igualmente, no sentido de conquistar o seu espaço de participação política, que se constituirá na grande força de pressão democratizante do sistema liberal monárquico, pressão que evoluirá para formas tanto mais radicais, quanto a monarquia constitucional se mostra totalmente incapaz de qualquer medida séria de reforma tendente ao enquadramento das forças emergentes da pequena burguesia urbana. Pelo contrário, o crescendo da «onda republicana» alimenta-se da crispação dos últimos governos rotativos (por exemplo, as medidas repressivas da ditadura de Hintze Ribeiro, 1894-97) e do estreitamento defensivo do sistema eleitoral (leis eleitorais crescentemente restritivas de 1894 e de 1901) reforço do carácter censitário do sufrágio, exclusão dos analfabetos do direito de voto, eliminação da representação das minorias, diluição do voto urbano pela redifinação dos circulos eleitorais). Medidas que não impedem o processo de desagregação dos partidos rotativos a partir de 1901, e a falência final do sistema anunciada pela ditadura de de João Franco (5) em 1907, ela própia ante-câmara do regicídio (1908) e da proclamação da Républica em 5 de Outubro de 1910.

Mas as contradições que opõem o bloco social dos marginalizados do sistema, liderado pelos republicanos, à oligarquia liberal monárquica, não são as únicas que se produzem na sociedade portuguesa finisecular. Por isso mesmo, a alternativa republicanista - a alternativa da reforma do sistema liberal pelo seu alargamento/democratização a novas camadas sociais até aí dele excluídas- se é a que politicamente se impõe em 1910 como solução superadora do impasse institucional a que chega a expressão monárquica do li-

(5) Joāo Franco. Figura destacada de um dos dois principais partidos da monarquia, o Partido Regenerador, abandona-o em 1901 e cria o Partido Regenerador Liberal, desenvolvendo um discurso e uma prática onde alguns autores encontram aspectos precursores do autoritarismo moderno. Chamado pelo rei à chefia do ministério em 1906, governará em ditadura de Abril de 1907 a 1 de Fevereiro de 1908, data do regicidio, por muitos visto como uma resposta às violências de ditadura franquista. 
beralismo português, isso não significa que fosse a única, ou sequer principal, que se gerara no processo de crise e transformação aberto em 90/91 (6).

É talvez preciso considerar a vertente económica e social dessa conjuntura para abarcar a dimensão verdadeiramente estrutural da crise que começa a ameaçar o liberalismo português, muito para além da simples contestação da forma monárquica do Estado.

$\mathrm{Na}$ realidade, as agudas dificultades financeiras dos anos 90 trazem consigo, antes do mais, a própria falência do modelo económico liberal da Regenação. Assentava ele, em termos muito gerais, por um lado, num livre cambismo agrícola tendo como parceiro privilegiado a Grã-Bretanha (e gerador de uma típica relação de dependência: o país especializado na exportação de produtos agrícolas - vinhos, frutas, carne, cortiça...- e constituído, apesar de algum proteccionismo às indústrias, como importador de máquinas, matérias primas industriais e produtos manufacturados); por outro, numa prática sistemática do défice orçamental e do endividamento interno e externo do Estado, financiadores dos grandes empreendimentos infraestrurais - caminhos de ferro e estradas- lançados na segunda metade do século. A crise internacional dos anos 90 vai atingir mortalmente tal política: a perca dos mercados agrícolas de exportação, o bloqueio do financiamento externo, o agravamento do défice comercial e da dívida externa, e sobretudo a inexistência de divisas para os solver - a bancarrota do Estado- empurram os grupos sociais dominantes para a imprescindibilidade de revisões mais ou menos profundas das suas estratégias económicas e políticas.

Para a débil e bloqueada burguesia industrial abre-se a oportunidade histórica de, face ao abrandamento da concorrência dos capitais e das mercadorias britânicas, face à debilitação do lobby do import/export, partir à conquista do mercado interno: substituindo importações, criando novas indústrias, transformando em seu proveito as matérias primas nacionais, etc. Para tal, ela pede ao Estado uma nova atitude de intervenção política e económica: que contenha as reivindicações operárias despoletadas com a industrialização neste último quartel, dado não ter poder económico que permita políticas sociais de enquadramento e diálogo; que proteja o mercado nacional e colonial da concorrência externa; que fomente a conquista de mercados externos; que compense com os seus financiamentos as carências de capital para o investimento industrial; que arbitre e componha os dissídios com os

(6) Não consideraremos aqui, por obviamente marginal aos propósitos deste trabalho, a "alternativa operária» ao regime monárquico liberal e depois à Républica, de alguma maneira formulada - por remota que fosse a sua viabilidade nas condições históricas da sociedade portuguesa de época - pelas corrientes socialista, anarco-sindicalista, e a partir de 1921 pela corrente comunista, que se foram sucedendo na liderança das organizações operárias portuguesas desde 1897. 
outros sectores da classe domiante. Apesar de, por circunstâncias que é dispensável para os propósitos deste trabalho serem aqui analisadas, não parecer poder falar-se de um take off industrial em Portugal neste período, de esta oportunidade não ter podido ser aproveitada para a imposição hegemónica de uma estratégia industrializante, o certo é que, não obstante, esta é a fase de um modesto mas real «surto industrial» (7), do surgimento dos primeiros rudimentos de indústrias básicas (cimentos, adubos fosfatados), da conquista da pauta proteccionista de 1892, da reserva do mercado colonial para a textil algodoeira. A burguesia industrial portuguesa sobe por essa via ao palco da cena económica e política. E o que é importante registar é que, desde o primeiro momento, por virtude das debilidades históricas do seu processo de acumulação, o faz fortemente apoiada na protecção e intervenção do Estado: o faz postulando uma concepção difusamente autoritária do papel do Estado que pouco tem a ver já com os paradigmas tradicionais do Estado liberal.

É curioso verificar que a crise leva as fracções da classe dominante hostis à estratégia da industrialização, a reivindicações formalmente idénticas quanto ao papel do Estado: os agrários do sul pedem -e obtêm (leis de 1889 e 1898) - a reserva do mercado interno para o trigo nacional; os grandes vinhateiros reclamam o exclusivo do mercado colonial, e ambos, «senhores do pão e do vinho», exigem medidas várias de intervenção estadual visando a contenção salarial e o fomento do produção e do lucro agrícola sem alteração -e possibilitando a conservação- das estruturas fundiárias tradicionais ameaçadas pelo fomento industrial.

De uma forma geral a crise de 90/91, gerando uma nova e desigual dinâmica de desenvolvimiento e de equilíbrio relativo entre os vários sectores de uma classe dominante globalmente débil, dependente, sem um sector claramente hegemónico, implicará, para o conjunto deles, a reformulação, inicialmente vaga e de conteúdos concretos variáveis para as diferentes estratégias, da concepção do papel e da natureza do Estado. O Estado que intervem economicamente, que acode aos sectores em crise, que protege, que financia, que constrói infrestruturas; o Estado dotado da força, da autoridade política e do prestígio indispensáveis para tal; um outro tipo de Estado que as alternativas autoritárias diferentemente começam a formular, produto de novas contradições e necessidades geradas pelas mudanças económicas e sociais da sociedade portuguesa -e não só delas- nos alvores do século XX. A superação, em suma, do liberalismo político e económico, não pela sua regeneração democratizante - republicana ou outra - mas pela rotura, pelo postulado de um diferente tipo de poder político de cunho anti-liberal e de

(7) Cf. Cabral, idem. 
raíz autoritária. O prolongado e acidentado processo histórico de decantação, clarificação e conciliação dos diferentes tipos de estratégia íncitos nesta(s) alternativa(s)s conduzirá à progressiva secundarização da questão da forma (republicana/monárquica) do Estado em favor da redefinição da sua natureza, isto é, levará ao Estado Novo.

\section{A FALENCIA DA ALTERNATIVA DEMOCRATIZANTE REPUBLICANA}

É sabido que a I República (1910-1926) falhou como tentativa de regeneração democratizante do liberalismo monárquico. Toda a sua história é a história do agitado processo agónico do liberalismo português, agora na sua final expressão republicana.

Si quisessemos, em jeito de síntese sumaríssima, sistematizar as razões principais da falência da alternativa democratizante-republicana falariamos em três grandes ordens de problemas:

- Em primeiro lugar, o cerco social do republicanismo. Fenómeno pequeno-burguês e essencialmente urbano, a revolta republicana triunfa em Lisboa e seus arredores mercê da favorável correlação de forças aí existente para o bloco social que a protagoniza, e é «proclamada pelo telégrafo» para o resto do país, ou seja, é passivamente consentida, sobretudo no mundo rural, mercê da situação particular de quase total isolamento social e político em que se encontra o regime monárquico e a que antes nos referimos. Mas o republicanismo chega ao poder num momento em que já começa a ser claro para a maioria das «forças vivas» (8) que a alternativa para o liberalismo monárquico não é democratismo republicano: fosse para o poderoso bloco do conservadorismo ruralista, fosse para as forças emergentes do industrialismo, a necessidade de um Estado forte, mantenedor da «ordem», economica e socialmente interveniente, isto é, não liberal, era questão acente. O que os levará, de uma forma geral, não obstante as contradições sobre tudo o mais que competiria a tal Estado fazer, a encarar com indisfarçada desconfiança e hostilidade a Républica, e a alimentar uma latente e constante actividade conspiratória contra ela. É bem certo, no entanto, que a Républica e o partido que nela representará o grande traço de continuidade da governação republicana -o Partido Democrático (9) de Afonso Costa e depois de António Maria da Silva - tentarão sempre esforçadamente conquistar a confiança das «forças vivas» ou, pelo menos, dos seus sectores industriais e de

(8) "Forças vivas". Designação empregue na linguagem política e jornalística dos primeiros 30 anos desde século para designar as forças económicas e sociais do patronato.

(9) Partido Democrático. Desginação porque foi conhecido o Partido Republicano Portugês quando, a partir de 1911, a sua direç̧ão passou a ser dominada pela ala radical e jacobina chefiada por Afonso Costa. 
import/export; convecê-los da sua competência e zelo para gerir o Estado e os seus interesses; ceder ao essencial das suas exigências. Mas, por paradoxal que isso pareça, tal atitude só agravou o isolamento social do republicanismo: porque foi insusceptível, no seu conjunto, de demover as classes dominantes do projecto autoritário de liquidação do liberalismo; e porque, no afã de aquietar os meios burgueses face ao crescendo da agitação social operária, os governos republicanos envolveram-se numa quase guerra permanente contra o movimento operário que acabaria por o cortar completamente deste seu aliado do « 5 de Outubro». Se em momentos cruciais de ofensiva das direitas o operariado ainda acorre a «defender a Républica» (contra as tentativas de restauração monárquica em 1919, contra as manobras e os golpes político-militares das «forças vivas» em 1924 e 1925), o certo é que ele acabará por assitir impassivel, quando não colaborante, ao golpe de misericórdia de 28 de Maio de 1926. Isolado das «forças vivas», cortado do movimento operário, os grandes momentos de crise económica e política farão desertar do republicanismo mesmo parte dos seus sectores tradicionais de apoio nas classes urbanas intermédias: é o que sucede com os efeitos da I Guerra, em 1917, e posteriormente com o impacto das medidas de valorização do escudo e de equilíbrio financeiro em 1924/25. Mais vulnerável que nunca, o republicanismo irá baquear. Primeiro, em Dezembro de 1917, durante o ensaio algo precoce de um «áutoritarismo moderno» resultante da revolta e do consulado sidonista (10), depois, com o «28 de Maio» de 1926 (11) que, rico das experiências anteriores, encerrará duradouramente a experiência de 92 anos de liberalismo em Portugal.

- Em segundo lugar, dever-se-à referir a impossibilidade/incapacidade do republicanismo democratizar o sistema político. Esta situação é simples de explicar: realidade social minoritária, e, como vimos, relativametne isolada, a pequena burguesia urbana republicanista e o seu Partido Democrático opõem-se ao alargamento e ao reforço da transparência e da representatividade do sistema político, o que para eles poderia significar o abandono da àrea do poder, senão o retorno a certa marginalização política. Caía-se, assim, nesta situação curiosa: à sua direita, o Partido Democrático desejava demonstrar a capacidade de governar no interesse e em nome das «forças vivas», mas para o poder fazer, tinha de impedir o acesso à direcção do Esta-

(10) Sidonismo. Regime político instaurado pela revolta militar de 5 de Dezembro de 1917 de que foi figura central o professor universitário, major do Exército e Presidente da Républica Sidónio Pais. Regime de rotura com o constitucionalismo republicano democrático, alguns autores vêm nele um ensaio precoce dos novos autoritarismos que vingarão na Europa do pós-guerra (cf. António Telo, Sidonismo, e o movimento/Operário Português, ed. Ulmeiro, Lisboa, 1977).

(11) Golpe militar que põe termo à I Républica instalando uma Ditadura Militar, fase de transição para a instauração do Estado Novo. 
do dos partidos que tendessem a assumir tal representação, designadamente os partidos da direita republicana que a isso expressamente se candidatavam. Contra essa concorrência à direita, o jacobinismo afonsista (12) lançará as suas milícias privadas («Formiga Branca», "Voluntários para a Defensa da Républica», etc.) assaltando sedes de jornais e de partidos, prendendo e intimidando, ou agitará a Lei de Separação das Igrejas e do Estado (de 1911) em perseguições político-religiosas - uma verdadeira acção de «terra queimada», tendente a manter, por meios alheios à concorrência política eleitoral, o monopólio do espaço de intervenção politica, o controlo do poder, alcançado entre Outubro de 1910 e 1913 (13).

O mesmo se passa, todavia, à sua esquerda: face à agitação operária que cresce na razão directa do seu desencanto com a Républica, esta irá adoptando medidas, por vezes, de excepcional violência (espingardeamento de manifestações, deportações sem julgamento, perseguições à imprensa, assaltos a sindicatos, prisões maciças, etc.) visando não só bloquear a participação/concorrência do operariado na vida política, mas sobretudo demonstrar às «forças vivas» a sua capacidade de «manter a ordem», de gerir o Estado contra os que ameaçavam a sua subversão. Esta recursa em chamar o operariado à participação política terá um elevado custo para a Républica e para o Partido Democrático: o proletariado organizado irá radicalizar a sua luta crescentemente à margem e contra o sistema político liberal, colocando-se progressivamente em clara rotura com a Républica. Naturalmente, esta acção repressiva à direita e à esquerda escourava-se na manutenção de um sistema político-institucional e eleitoral que, contrariando as promessas republicanas, não conhece qualquer democratização significativa:

a) O Partido Democrático, principal herdeiro da máquina eleitoral e do cacicato dos partidos monárquicos, passa a fabricar, só que agora sem parceria rotativa, os actos eleitorais: ganhará assim, sem surpresas, 5 das 6 eleições parlamentares a que concorre durante a I Républica. O monopólio político, a «ditadura do P. Democrático», torna-se assim inderrubável pela via eleitoral: ele só cederá o lugar ou pela via da força, do golpe militar, ou, frequentemente, face ao risco daquele, quando o faz por conveniência própria. E é também normalmente pela força que, quando por ela arredado, irá recuperar o poder.

b) A legislação eleitoral de 1911, 1913 e 1915 não cumpre a promessa do sufrágio universal: continuará a negar o direito de voto às mulheres e aos

(12) Afonsista. De Afonso Costa, ver nota 9.

(13) Em 1913 têm lugar eleições parciais que dão a maioria parlamentar ao Partido Democrático. 
analfabetos, o que exclui a maioria dos operários industriais e a enorme massa da população camponesa. Não nos esqueçamos que, em 1920, mais de $65 \%$ da população é analfabeta. Nas eleições de 1921, por exemplo, o número de votantes corresponde a $5,8 \%$ do total da população, sendo a percentagem dos com direito a voto de $11,2 \%$.

c) O impasse do sistema institucional exprime-se assim num paralamento simultaneamente de limitada representatividade e, até 1919, constitucionalmente indissolúvel pelo própio Presidente da Républica. Mas mesmo depois de consagrado o direito de dissolução, ele em nada contribui para assegurar a alternância, dado o controlo do $\mathrm{P}$. Democrático sobre a máquina eleitoral. Estavam, assim, criadas as condições para a instabilidade política e a ameaça permanente de subversão do sistema: de 5 de Outubro de 1910 a 28 de Maio de 1916 a I Républica conhecerá 45 governos e 29 intentonas revolucionárias.

- En terceiro lugar, e por último, regista-se a ausência de uma «ideia de Estado», de um projecto político ou económico próprio do republicanismo e dessa forma susceptivel de aglutinar um bloco social de apoio estável e estabilizador. Essa circunstância, sem dúvida atribuivel à instabilidade governativa que caracteriza a I Républica, à ocorrência da I Guerra, etc., tem talvez algo a ver com realidades mais profunda: com a própria especificidade política, ideológica, mental da base social do republicanismo. Uma amálgama de estratos sociais urbanos intermédios, com uma coesão mais ditada por objectivos imediatos de promoção (ou de sobrevivência) social e política, mas tendendo, no seu comportamento quanto aos objectivos estratégicos, à atracção pelos grupos sociais polarizados e de contornos e actuação social e política mais afirmada.

O que é facto é que o republicanismo chega ao poder defendendo desde sempre o primado da "questão política», portanto, com algumas ideias político-institucionais imediatas - as indispensáveis à abertura do espaço institucional para a intervenção política da pequena burguesia urbana- mas sem quaisquer precisões programáticas no domínio das reformas económicas e sociais.

Esta actuação, mais denotadora de um certo padrão de comportamento sociológico do que de uma consciente pretensão de ocultação política, vai pautar a governação republicana: feita essencialmente da gestão de um quotidiano de crises e pressões, sem uma estratégia de fundo coerente visível, balançando ao sabor dos safanões da conjuntura, pretendendo sobretudo demonstrar a sua capacidade de governar para outrém mais do que por si própia. É isso que empresta à I Républica essa sensação - que parece, aliás, corresponder à realidade histórica do período- de transição para «outra coisa». 
Os momentos raros onde parece definir-se um esboço de política económica coerente -o equilibrio orçamental de Afonso Costa, em 1913, a política de estabilização financeira de Álvaro de Castro, em 1924- não tẽm nem continuidade em si próprios, nem possibilidade de articulação com outros objectivos e medidas. E aquilo que mai se assemelhou com a formulação de uma certa ideia do «papel de Portugal no mundo» e com o traçar de um caminho para o alcançar - a política do intervencionismo na I Guerra mundialtraduziu-se numa manifestação típica do voluntarismo republicanista: o desejo de regenerar Portugal a golpes de audácia e de diplomacia - de ideologiasem tocar nos factores estruturalmente condicionantes da dependência e do atraso do país. A intervenção assim concebida e executada iria, aliás, com o seu cortejo de dramáticos efeitos económicos, sociais e políticos, agudizar todas as dificuldades e contradições do regime, precipitando-o numa crise, à qual, em última análise, ele acabaria por não sobreviver.

Da I Républica ficaria, no entanto, como permanência cultural, cívica e mental importantíssima - talvez nem sempre devidamente considerada por alguma historiografia recente de desmontagem da tradição historiográfica de exaltação republicanista - a obra de laicização do Estado e da sociedade civil, peça fundamental da sua modernização em termos democráticos. A separação das Igrejas e do Estado, as leis da família, do divórcio, do registro civil, foram aquisições culturais e cívicas definitivas da mentalidade democrática portuguesa, nas quais o próprio Estado Novo, quanto ao essencial, não lograria mexer.

\section{AS ALTERNATIVAS AUTORITÁRIAS. AS «DUAS DIREITAS»}

Foram os trabalhos de M. Villaverde Cabral (14) que na hitoriografia portuguesa primeiramente chamaram a atenção, ao arrepio de certa tradição historiográfica liberal, para a necessidade de não confundir as manifestações precursoras daquilo a que chamou o «autoritarismo moderno» - designadamente o franquismo e o sidonismo (15) - com o ultramontanismo absolutista e tradicionalista.

A observação e a pista que elas abrem parecem-me essenciais para uma melhor compreenção da história portuguesa do século XX em geral, e do fenómeno político, económico e social do Estado Novo em particular, de tal forma a dinâmica de contradição/arbitragem entre essas «duas direitas» informa a génese e a natureza do regime salazarista.

(14) Cf. Cabral, ob. cit. e "A "segunda républica" portuguesa numa perspectiva histórica» in Análise Social vol XIX (75), 1983, 1., págs. 127-142.

(15) Ver notas 5 e 10 respectivamente. 
A assimilação num mesmo fenómeno reaccional desses dois tipos de discurso autoritário tem, todavia, alguma razão de ser decorrente do próprio processo histórico da crise do liberalismo e da ascensão do autoritarismo em Portugal.

Antes do mais, porque ambos são uma reacção aos mesmos problemas, são respostas, tentativas, de superação da crise do capitalismo concorrencial e do Estado liberal iniciada na transicção do século. Por isso, quer os grupos sociais emergentes desse processo de transformação, quer os política e socialmente ameaçados no seu estatuto tradicional; quer os arautes da modernização, quer os paladinos da conservação, desenvolvem um discurso formalmente idêntico: criticam a instabilidade política e social a que o sisma daria origem, pedem a «moralização» da vida pública, a «ordem», um Estado «forte» politica e financeieramente que, por esta via, possa ser um activo protagonista da vida económica, etc.

Há um invólucro reivindicativo formalmente idêntido que, ocultando embora profundas diferenças de estratégia entre os grupos sociais dominantes, e entre estes e os sectores intermédios que aderem a tal discurso, parece evidenciar a aceitação de uma base mínima política, institucional, económi$\mathrm{ca}$, de actuação comum para a redefinição do Estado e a superação do liberalismo.

Ora é precisamente isso que historicamente se verifica, o que não ajuda à clarificação distintiva que o fenómeno merece. Ou seja, nas crises cruciais do liberalismo posteriores à implantação da Républica - a crise da Grande Guerra, a crise do início dos anos 20- as "duas direitas" unem-se e confundem-se num equilíbrio instável para conspirar e derrubar o regime, primeiro, e depois, ainda que com evidente e crescente conflitualidade entre si, para tentar governar em moldes novos (experiência sidonista de 1917-18, Ditadura Militar e Estado Novo posteriormente a 1926). Esse comportamento parece-me particularmente característico da classe dominante portuguesa do primeiro quartel do século vinte, aspectos a que já antes aludimos: fortemente atingida pela crise do sistema, globalmente débil e dependente, sem sectores claramente capazes de hegemonizar um programa político e económico próprio ou de gerar os correspondentes movimentos políticos. Por tudo isto, fortemente dividida numa luta desesperada pela defesa dos seus interesses, mas, por tudo isso também, tendo necessariamente de conjugar forças -através de laboriosos esforços políticos e organizativos- para os grandes passos de interesse comum, e precisando vitalmente da intervenção do Estado (contra as reivindicações operárias, socorrendo os sectores em crise, regulando a concorrência, arbitrando os dissídios intestinos) para sobreviver e prosperar. O Estado Novo virá realizar com êxito duradouro a síntese da 
experiência de sucessos e fracassos das direitas portuguesas. Como noutro local procurei demonstrar (16), ele representa a estabilização de um equilíbrio arbitrado pelo salazarismo entre as «duas direitas», entre as forças da modernização e as da conservação na classe dominante, e entre esta e os sectores intermédios, num compromisso ideológico e político de raiz autoritária, anti-liberal e anti-democrática, e onde coexistem contraditoriamente os elementos de desenvolvimiento e os de estagnação no plano económico.

Se assim é, poder-se-à questionar qual o interesse operacional de distinguir «duas direitas», dois discursos autoritários que só são acção, só são poder, quando se confundem e, em certa medida, se anulam. A dúvida não me parece de pôr: insisto em que o entendimento do processo histórico de ascenção do autoritarismo moderno e do advento Estado Novo português nos seus acidentes, nas suas hesitações, na sua conflitualidade, nas suas «incoerências», em suma, nas suas especificidades nacionais, passa em boa medida pela detecção e aprofundamento desta disntinção e da sua dinâmica histórica. São uma ou duas ideias sumárias ainda sobre ela que, rapidamente, pretenderia registar.

Praticamente ausente da vida política e cultural dos últimos tempos da monarquia constitucional, o ultramontanismo absolutista, o pensamento da direita passadista e tradicionalista portuguesa, é como que redescoberto e remoçado através de um novo tipo de discurso pelo «Integralismo Lustitano» (17), a partir de 1913, ou seja, no contexto da reaç̧ão anti-republicana.

Com ligações tardias (e mesmo assim acidentadas e passageiras) com a corrente monárquica legitimista, com origens sociais e culturais quase sempre muito distintas dos velhos próceres miguelistas (18), a jóvem pleíade intelectual que se agrupa no Integralismo Lusitano vai, não obstante, recriar o pensamento do reaccionarismo conservadorista português através da matriz maurassiana. É inegável a enorme e duradoura influência de muitos dos valores do munus integralista na política e na filosofia do conjunta da direita portuguesa. A crítica do parlamentarismo e do «demo-liberalismo» em geral e a contraposição que lhe é feita da «representação orgânica» corporativa, superadora da luta de classes - essa «invenção» do capitalismo e do socialismo; a apologia de um «Estado forte», ditatorial, onde governasse- em contraste

(16) Fernando Rosas, O Estado Novo nos Anos Trinta, ed. Estampa, Lisboa, 1987.

(17) Integralismo Lusitano. Movimento doutrinário iniciado por intelectuais monárquicos exilados na Bélgica, em 1913, em torno da revista Alma Portuguesa e depois politicamente constituído, em 1914, em Coimbra, ao redor da revista Nação Portuguesa. É fortemente influenciado pela Action Française e o pensamento de Charles Maurras.

(18) Miguelistas. Partidários do rei D. Miguel, monarca do regime absoluto derrubado pela revolução liberal vitoriosa em 1834 . Os seus adeptos e os dos seus sucessores designavam-se por legitimistas. 
com o clientelismo e a corrupção dos partidos - a elite dos «melhores"; a exaltação de um nacionalismo passadista, com o qual se reencontraria nas suas tradições a nação «resgatada» de um século de liberalismo- são um conjunto de ideias que as classes dominates e a direita em geral integrarão como seu património comum no combate ao republicanismo liberal.

Mas é evidente que ideias como a defesa à outrance da restauração monárquica enquanto objectivo político central; a origem divina da legitimidade do monarca absoluto; a apologia do ruralismo (restauração do morgadio, defesa do latifundio, oposição à urbanização e ao progresso industrial); a denúncia do cientifismo ateu e do avanço técnico; o regresso à descentralização municipal tutelada pelos senhores locais, etc. nada dizem, quando não dizem mesmo o contrário de que eles pretendem, aos sectores modernizantes da burguesia. Por isso, elas se constituiram em factores de indiscutivel divisão da direita anti-liberal: basta atentar no papel que teve a precipitada restauração da monarquia no norte do país, em Janeiro de 1919, no falhanço do sidonismo, para se ver que assim é. Na realidade, se das entranhas da crise do liberalismo sai esta espécie de passadismo restaurado tendencialmente ligado aos grupos sociais dominantes tradicionais, mais ameaçados pelas trasnformações agudizadas pela crise - sai também um outro tipo de discurso que pretende abrir caminho às camadas sociais em ascenção pretemões a tal. Um autoritarismo que aponta não para trás, para o regresso utópico ao Antigo Regime, mas para a adaptação do Estado a novas condições de desenvolvimento do capitalismo. O Estado Novo a especial modalidade do fascismo nacional, acabará per ser, já o referimos, a resultante histórica do equilíbrio entre as estratégias destes sectores modernizantes e as dos grupos mais conservadores e do conjunto des classes dominantes com os sectores intermédios. Mas o que o faz política, institucional, economicamente moderno, isto é distinto do tradicional reacçionarismo ruralista, é ele ser uma resposta, não obstante os seus compromissos e equilíbrios, às novas contradições e aspirações resultantes do crescimento do capitalismo, e não o prolongamento tardio, século XX adentro, das relações sociais e políticas do Antigo Regime.

\section{O «AUTORITARISMO MODERNO»}

Tal carácter modernizante - no sentido que aqui atribuímos à expressãoestá claramente presente em certos pontos-chave especificos da teoria e da prática deste novo tipo de autoritarismo desde as suas primeiras manifestações, para além das ideias que ele herdou e reelaborou do integralismo e que já antes aflorámos. Entre eles se poderá referir:

- A associação da apologia do Estado autoritário e economicamente in- 
tervencionista à execução de um plano de «realizações materiais", de fomento económico, aliás, geralmente de cariz nacionalista e proteccionista. Não é certamente por acaso que encontramos quase todas as principais figuras que pensaram Portugal em termos de desenvolvimento económico desde fins do século $\mathrm{XIX}$ aos anos trinta do século $\mathrm{XX}$, de alguma forma ligados à teorização autoritária ou às suas experiências: de Oliveira Martins e Basilio Teles a Quirino de Jesus, Ezequiel de Campos ou Araújo Correia, sendo sabido como a ideia da "ditadura temporária» e regeneradora seduziu os seareiros (19) nas vésperas do 28 de Maio. Na realidade, já o franquismo fará alarde de um programa de fomento e de obras públicas, sendo publicamente apoiado pelos interesses económicos da época mais expressivamente ligados ao desenvolvimento técnico e industrial (família Sommer, Alfredo da Silva, e outros "grandes capitalistas"); o sidonismo, que contará com apoios idênticos e mais vastos entre a «burguesia produtiva», apoia-se num partido em cujo programa se conjugavam o ideário desenvolvimentista neofisiocrático de $\mathrm{O}$. Martins e Ezequiel de Campos (20); o salazarismo, finalmente, insistirá na crítica ao "capital improdutivo» e à «plutocracia», tendo como imagem emblemática os seus planos de «regeneração financeira» e de «reconstitução económica» e «obras públicas».

- A intuição da necessidade de uma chefia carismática, de um novo tipo de liderança política adequada à conjuntura de crise, do ruir dos valores e das instituições, do "caos» da guerra, da fome, do desemprego, e que explorasse demagogicamente, messianicamente, o desespero das grandes massas, assente na relação pessoal com elas estabelecida pelo «chefe», o «salvador», o grande àrbitro, arauto de uma solução «nacional» e «redentora», acima das classes, dos partidos, da "política» em geral. É o que encontramos já no cesarismo régio reclamado por Oliveira Martins, na mass politics que João Franco inaugura como política dos partidos «da ordem» (21), ou mais claramente com Sidónio Pais. É, já sob a influência fascista e nacional-socialista, a postura que os "camisas azuis» (22) exigem que Salazar assuma nos anos trinta, e que o «Chefe» do Estado Novo temperará com o particular caldo social, mental e ideológico que cacterizará esse regime em Portugal.

(19) Cf. Egas Moniz, Um ano de politica, ed. Portugal-Brasil Lda., Lisboa (1919), págs. 60 e segs. e págs. 92 e segs.

(20) «Seareiros». Membros da revista Seara Nova, publicação da esquerda republicana fundada em 1921, e ainda existente, que reuniu o escol do pensamento democrático durante dezenas de anos.

(21) Cf. Cabral, idem.

(22) «Camisas azuis». Farda dos membros do Movimento Nacional-Sindicalista, organização radical de tipo fascista fundada em 1932 e que será ilegalizada pelo Estado Novo em 1934. O seu «Chefe» era o ex-integralista Rolão Preto. 
- O populismo moderno: ligado à característica anterior, ele subentende o corporativismo mos é algo maıs que este, isto é, que a negação da luta de classes assente numa concepção orgânica e integral da nação de raiz corporativa, largamente teorizada por toda a direita portuguesa, com um primeiro assomo institucional no Senado sidonista e consagrada como forma de organização e enquadramento das actividades económicas e não só, com o Estado Novo. O populismo, o apelo directo do "chefe» e do regime à massa passando por sobre as suas organizações tradicionais, a tentativa de a mobilizar para impôr ou defender "revolucionariamente» a nova situação contra o capitalismo e o socialismo, como uma terceira via simultaneamente nacional e social ou sindical, está presente em embrião nessa maneira sem precedentes que João Franco inaugura de «um homem de Estado português se dirigir tão de perto a multidão» (23). Ressurge no frustado diálogo que o sidonismo, no seu início, tenta estabelecer com as organizações operárias (24), depois, no discurso «operário» dos pequenos grupos e movimentos fascizantes que, saídos do integralismo, surgem em Portugal desde o início dos anos vinte, dos quais o mais tipicamente representativo virá a ser o Movimento Nacional-Sindicalista de Rolão Preto. Mas não será nunca uma característica relevante do Estado Novo português, combinatória social e política específica de classes dominantes e intermédias que sempre encararão com total desconfiança -e até como um perigo - todos os movimentos de mobilização de massa, por definição potencialmente incontroláveis, mesmo que para apoiar o regime.

- A subalternização da «questão do regime», da forma do Estado (republicana ou monárquica) em favor da definição e imposição de um novo tipo de Estado: anti-liberal, anti-parlamentar, anti-democrático, anti-socialista, corporativo e autoritário. Este é um dos pontos de política e de táctica que mais tipicamente dividirá a «nova direita» dos velhos monárquicos da primeira geração integralista. Tendo assimilado a lição da derrota da sua primeira experiência histórica de reorganização anti-liberal do Estado em novos moldes -o sidonismo, deitado a perder, entre outras causas, por via da divisão criada no seu bloco social de apoio pelo restauracinismo monárquico- as classes dominantes procuram e conseguem unir-se, nos anos vinte, em torno do essencial para o assalto decisivo ao poder. O compromisso político-institucional que estrutura a fronda social do Estado Novo passará pela aceitação da for-

(23) Rocha Martins, Portugal dos nossos dias - vermelhos, bracos e azuis, vol. I, Vida Mundial, Lisboa, 1948, p. 31.

(24) Cf. Cabral, «A grande guerra e o sidonismo (esboço interpretativo)» in Análise Social, vol. XV (58), 1979, 2., págs. 373 a 392. 
ma republicana do Estado, mesmo que ao preço da rotura com os grandes vultos fundadores do integralismo.

- A concentração política do aparelho repressivo e a criação de organizações milicianas. Neste domínio, todos os ensaios autoritários em Portugal, do franquismo em diante, buscarão criar ou reforçar e centralizar, de acordo com as necessidades e princípios políticos do regime, um corpo policial secreto, especializado na informação e na repressão política violenta, rapidamente transformado em peça central do aparelho repressivo e instrumento decisivo da sobrevivência da situação instalada. Se, com as perseguições do Juízo de Instrução Criminal, na ditadura de João Franco, ainda se está na infância da «arte», já a repressão massiva e as violências da polícia secreta sidonista de Sollari Alegro (25) constituirão uma significativa antecipação da Polícia de Vigilância e Defensa do Estado (P.V.D.E.), fruto final da reorganização e centralização das polícias operada por Salazar em 1933. Para o que, diga-se de pasagem, foi de decisiva importância o contributo das polícias republicanas, deselvolvidas e aperfeiçoadas nos anos 20 na repressão ao movimento operário.

As organizações milicianas por seu lado, têm um papel de maior subalternidade no processo de ascenção e consolidação do autoritarismo moderno em Portugal. Não tendo este assentado, entre nós, no «assalto» ao poder liderado por pattidos ou movimentos de massa para-militares (a aproximação nesse sentido do Movimento Nacional-Sindicalista é de consequências práticas quase irrelevantes), as organizações milicianas -encaradas com franca desconfiança pelo Exército, tutor da «Revolução Nacional» - surgirão entre nós tardiamente (26), sobretudo por inflûencia da Guerra Civil de Espanha, ligadas à defesa e consolidação do regime face à «ameaça vermelha» espanhola, e sempre estritamente controladas e na dependência orgânica do Estado.

- A necessidade de um «partido único»: ele foi historicamente, em Portugal, um instrumento orgânico essencial à viabilização e triunfo do autoritarismo moderno. Não no sentido comum que se empresta à ideia, de um movimento vanguardista e dirigente da conquista do poder - são outros os camnhos de tomada do poder pelas direitas portuguesas - mas no sentido mais geral da imprescindibilidade de uma prévia definição institucionalizada da pla-

(25) Sollari Alegro. Político monárquico sidonista que reorganizará e chefiará a polícia política da «República Nova» no norte do país, tristemente celebrizada pelas violências cometidas sobre os presos políticos.

(26) Após a curta vida activa duma Associação Escolar Vanguarda surgida em 1934 como organização da juventude, o Estado Novo cria em 1936, sob a sua estreita tutela, a Mocidade Portuguesa e a Legião Portuguesa, organizações milicianas para-militares que usarão o verde como côr das camisas das suas fardas. 
taforma comum unificadora das estratégias políticas e económicas de uma classe dominante tão caracteristicamente débil e dividida como vimos ser portuguesa do primerio quartel do século XX. Já Sidónio Pais intuira a importância vital da questão para a sobrevivência da sua «Républica Nova», ao lançar o frustado projecto de um «partido único» do sidonismo, em 1918, o Partido Nacional Republicano, e ao substituir-lhe - face à falência do projecto- a sua figura pessoal como factor último de congregação. Mas são os políticos do Centro Católico (27) de Salazar que mais longa e laboriosamente trabalham nesse projecto compromissório de «toda a burguesia", desde os años 20. Conseguida uma operacionalidade mínima para o «28 de Maio» de 1926, através de uma rede frágil e complexa de organizações patronais e políticas unificadoras (logo perdida na acesa disputa que se sucede à Ditadura Militar) será finalmente a União Nacional, em 1930, a fixar as bases do acordo político e social comum viabilizador do Estado Novo. Obra de Salazar, a sua própria figura, o seu papel individual, serão um factor pessoal decisivo na definição, salvaguarda e arbitragem da plataforma assim definida. Partido subalterno e dependente do Estado, sem força anímica própria, sem autonomia, a União Nacional, a par de instituições como a Assembleia Nacional, têm, todavia, a importância, nem sempre imediatamente perceptível, de funcionarem como orgãos de uma frente política, ou seja, como pontos de encontro, areópagos de diálogo, composição e arbitragem de interesses entre os diversos sectores dos grupos sociais dominantes, elementos institucionais sem os quais seria questionável a estabilidade e a própia viabilidade do novo regime.

Do que ficou dito se poderão talvez detectar duas particularidades mais salientes do porcesso de crise do liberalismo português desde a última década do século XIX: por um lado, o seu caracter prolongado, quase arrastado, no contexo do qual coexistem a falência da reforma democratizante-republicana do sistema, a inviabilidade da alternativa revolucionária-operária, a relativa dificuldade, pautada por várias tentativas ao longo de mais de um quartel, de as classes dominates se entenderem para a imposição da sua alternativa autoritária e anti-liberal; por outro lado, este último aspecto, que se liga ao contexto económico, social e mental específico da sociedade portuguesa da époa, acabou por condicionar o particular perfil político, económico e ideológico do Estado Novo português. Apesar de nele encontramos os traços essenciais do «autoritarismo moderno» de entre as duas guerras, o seu caracter

(27) Centro Católico. Partido católico ligado à Igreja fundado em 1894 e reorganizado em 1919. Nele se destacará, nos anos vinte, como figura central, Oliveira Salazar. O Centro Católico desenvolveu uma acção decisiva pela unificação das forças conservadoras, advogando a subalternização da questão do regime. 
equilibrante, compromissório e arbitral entre factores de mudança e de estagnação ditará um regime de onde estarão ausentes, ou só moderamente presentes, alguns dos aspectos político-ideológicos típicos de outras experiências fascistas coevas: o revolucionarismo populista, a exacerbação do fhürerprinzip, o culto da força e da violência, o racismo, as «tropas de assalto» milicianas, ou mesmo boa parte da grandiosidade iconográfica desse tipo de regimes.

O longo e nem sempre fácil parto do «autoritarismo moderno» português faria nascer esse particular Estado Novo, onde as modernas industrias cimenteiras, adubeiras ou de refinação do petróleo cresceriam e se concentrariam, nos anos trinta, à sombra da cruz e da espada, embaladas no culto da gesta passada de nautas, santos e cavaleiros e na oratória exaltante das excelências da vida rural.

Lisboa, 9 de Julho de 1987. 